\title{
Does the Hitit Index Work in the Differential Diagnosis of CCHF and COVID-19 with Non-Specific Findings?
}

\section{Hitit İndeksi, Spesifik Olmayan Bulgularla KKKA ve COVID-19 Ayırıcı Tanısında İse Yarar Mı?}

Derya YAPAR'(IID), Özlem AKDOG̃AN'(IiD), Hüseyin KAYADiBi²(IiD), Gülcan KAPLAN'(IiD), PInar TUNÇEL ÖZTÜRK'(IID), Aysel KOCAGÜL ÇELIKBAȘ'(İD), Nurcan BAYKAM'(IID)

\footnotetext{
${ }^{1}$ Department of Infectious Diseases and Clinical Microbiology, Hitit University Faculty of Medicine, Çorum, Turkey

${ }^{2}$ Department of Medical Biochemistry, Hitit University Faculty of Medicine, Çorum, Turkey
}

Cite this article as: Yapar D, Akdoğan Ö, Kayadibi H, Kaplan G, Tunçel Öztürk P, Kocagül Çelikbaş A, et al. Does the Hitit index work in the differential diagnosis of CCHF and COVID-19 with non-specific findings?. FLORA 2021;26(3):426-32.

\begin{abstract}
Introduction: During the 2019 novel coronavirus (COVID-19) pandemic period, all cases admitted to the emergency services have been evaluated primarily for COVID-19, and therefore other infectious diseases, especially Crimean Congo Hemorrhagic Fever (CCHF), which are endemic in our region, can be overlooked. In this study, it was aimed to determine the diagnostic power of the Hitit Index, which we developed from a panel consisting of clinical and laboratory findings of the cases with and without CCHF in previous years, to distinguish CCHF cases from COVID-19 cases.

Materials and Methods: The study groups consisted of the COVID-19 cases ( $n=116)$ admitted to the emergency service and the CCHF patients $(n=110)$ who were followed up in the Infectious Diseases and Clinical Microbiology Clinic of the same hospital between 2015-2020.

Results: Hitit Index was found to be statistically significantly higher in patients with CCHF. For Hitit Index, sensitivity and specificity were $88 \%$ and 99\%, while negative predictive value (NPV) and positive predictive value (PPV) were $90 \%$ and 99\%, respectively.

Conclusion: The Hitit Index is an example of artificial intelligence that we can use to distinguish patients with CCHF from patients with COVID-19.

Key Words: COVID-19; Crimean-Congo hemorrhagic fever; Differential diagnosis; Hitit index
\end{abstract}


ÖZ

\title{
Hitit İndeksi, Spesifik Olmayan Bulgularla KKKA ve COVID-19 Ayırıcı Tanısında İșe Yarar Mı?
}

\author{
Derya YAPAR', Özlem AKDOG̃AN', Hüseyin KAYADiBi², Gülcan KAPLAN', Pınar TUNÇEL ÖZTÜRK', \\ Aysel KOCAGÜL ÇELIKBAȘ', Nurcan BAYKAM'
}

\footnotetext{
${ }^{1}$ Hitit Üniversitesi Tıp Fakültesi, İnfeksiyon Hastalıkları ve Klinik Mikrobiyoloji Anabilim Dalı, Çorum, Türkiye

${ }^{2}$ Hitit Üniversitesi Tıp Fakültesi, Tıbbi Biyokimya Anabilim Dalı, Çorum, Türkiye
}

Giriş: Yeni koronavirüs 2019 (COVID-19) pandemi döneminde acil servislere başvuran tüm vakaların öncelikle COVID-19 olarak değerlendirilmesi nedeniyle özellikle bölgemizde endemik olan Kırım-Kongo Kanamalı Ateşi (KKKA) başta olmak üzere diğer bulaşıcı hastalıklar gözden kaçabilir. Bu çalışmada, önceki yıllarda KKKA olan ve olmayan olguların klinik ve laboratuvar bulgularından oluşan bir panelden geliştirdiğimiz Hitit indeksi'nin KKKA olgularını COVID-19 olgularından ayırt etmedeki tanısal gücünün belirlenmesi amaçlanmıştır.

Materyal ve Metod: Çalışma grupları 2015-2020 yılları arasında acil servise başvuran COVID-19 vakaları (n=116) ve aynı hastanenin infeksiyon Hastalıkları ve Klinik Mikrobiyoloji Kliniğinde takip edilen KKKA hastalarından $(n=110)$ oluşturuldu.

Bulgular: KKKA'ı hastalarda Hitit Indeksi istatistiksel olarak anlamlı derecede yüksek bulundu. Hitit indeksi için duyarlılı ve özgüllük $\% 88$ ve \%99 iken, negatif tahmin değeri (NPV) ve pozitif tahmin değeri (PPV) sırasıyla \%90 ve \%99 idi.

Sonuç: Hitit Indeksi, KKKA'lı hastaları COVID-19'lu hastalardan ayırt etmek için kullanabileceğimiz bir yapay zeka örneğidir.

Anahtar Kelimeler: COVID-19; Kırım kongo kanamalı ateşi; Ayırıı tanı; Hitit indeks

\section{INTRODUCTION}

In December 2019, a viral infection called COVID-19 caused by a $\beta$-coronavirus was identified in Wuhan, China, which can cause different clinical pictures from asymptomatic cases to severe respiratory failure and death ${ }^{[1]}$. The virus spread rapidly around the world, causing a serious pandemic and it took place in Turkey as well. In the province of Corum, where CCHF has been seen endemically since 2002, $\mathrm{CCHF}$ cases have started to be seen together with COVID-19 cases since the end of March 2020. There was a concern that there might be difficulties in distinguishing $\mathrm{CCHF}$ cases from COVID-19 in emergency outpatient conditions, especially in the pre-haemorrhagic period, due to the presence of similar clinical symptoms such as fever, malaise, anorexia, headache, muscle and joint pains in the course of both infections and similarities in some laboratory findings ${ }^{[2-4]}$.

In emergency outpatient clinic conditions, it is important to quickly distinguish COVID-19 from $\mathrm{CCHF}$ infection, which is seen in the spring and summer months in endemic regions, in order to plan the treatment of the cases and to apply the necessary isolation measures to control two infections having different transmission routes.

In this study, it was aimed to determine the diagnostic power of the Hitit Index, which we developed from a panel consisting of the clinical and laboratory findings of cases with and without $\mathrm{CCHF}$ in previous years, to distinguish $\mathrm{CCHF}$ cases from COVID-19 cases.

\section{MATERIALS and METHODS}

\section{Study design and laboratory parameters}

The study groups consisted of the COVID-19 cases admitted to the emergency service at XXXXX Training and Research Hospital between 01.03.2020 and 09.06.2020 with PCR positivity, in addition the CCHF patients over 18 years of age, who were followed up in the Infectious Diseases and Clinical Microbiology Clinic of the same hospital between 2015-2020 with Polymerase Chain Reaction (PCR) positivity.

The diagnostic power of Hitit Index to distinguish COVID-19 cases from CCHF cases was evaluated by comparing the Hitit Indexes and the parameters that consist Hitit Index. 
The formula of Hitit Indexis given below ${ }^{[5]}$ :

5.6 - (5.3 x lymphocyte) - (0.02 x fibrinogen) $(12 \times$ direct bilirubin $)+(0.04 \times$ AST $)+(0.32 \times$ hematocrit) - (0.5xneutrophil) - (0.07 x CKD - EPI)

$(0.001 \times \mathrm{CK}) \pm$ conjunctival hyperemia $(+1.5$ in conjunctival hyperemia presence and - 1.5 in conjunctival hyperemia absence).

AST: Aspartate aminotransferase, CKD-EPI: Chronic Kidney Disease Epidemiology Collaboration, CK: Creatine kinase.

In our previous study, the independent effect of each variable was assessed by using univariate logistic regression analysis, and then significant parameters were evaluated with the multivariate logistic regression analysis to create the laboratory and clinical sections of the Hitit Index. The diagnostic accuracy of the Hitit Index was assessed by calculating the areas under the receiver operating characteristic (ROC) curves, accuracy, sensitivity, specificity, PPV and NPV. All reported $\mathrm{p}$-values were two-tailed, and those less than 0.05 were considered statistically significant, but for univariate logistic regression analysis P-values less than 0.10 were accepted as statistically significant ${ }^{[5]}$. The cut-off point was calculated as zero to distinguish patients with CCHF from non-CCHF. Patients with Hitit Index less than zero were considered as non-CCHF and more than zero were considered as CCHF.

Necessary approvals were obtained from the Republic of Turkey Ministry of Health, XXXXXXX Training and Research Hospital, and the Hitit University Faculty of Medicine Clinical Research Ethics Committee (date: 17.06.2020 and Decision No: 269) for this research.

\section{Diagnostic Tests}

All laboratory test results required for this study were obtained from the hospital automation system. Combined oropharynx and deep nasal swab samples taken for the real-time PCR (RT$\mathrm{PCR}$ ) test used for the diagnosis of COVID-19 were stored in viral transport media at $+4^{\circ} \mathrm{C}$ until the time of the study. COVID-19 PCR test was performed in our hospital's Medical Microbiology PCR Laboratory. Bio-Speedy ${ }^{\circledR}$ SARS-CoV-2 (2019-nCoV) qPCR detection kit was used to perform manual extraction in the analysis. While LightCycler ${ }^{\circledR} 96$ RT-PCR System (Roche Molecular Systems, Inc.) and Montania 4896 RT-PCR System (Anatolia Geneworks) were used for RTPCR, Bio-Speedy ${ }^{\circledR}$ COVID-19 RT-qPCR detection kit version 3-1000 Rxn was used as PCR kit. CCHF PCR Test was conducted in Republic of Turkey Ministry of Health, Ankara Public Health Virology Laboratories.

\section{Statistical analysis}

Hitit University licensed SPSS 23 package program was used for statistical analysis. Kolmogorov-Smirnov test was applied in order to understand whether the groups were normally distributed or not. Categorical variables were given as numbers and percentages, while continuous variables with normal distribution were given as mean \pm standard deviation, and continuous variables not showing normal distribution were given as median $\left(25^{\text {th }}-75^{\text {th }}\right.$ quartile). Chi-square test was used to determine whether there is a difference between categorical variables. Student's t-test was used to determine whether the normally distributed continuous variables showed a statistically significant difference between the two groups, and the Mann-Whitney $\mathrm{U}$ test was used to determine whether the continuous variables that did not have a normal distribution showed a statistically significant difference between the two groups. Sensitivity, specificity, PPV and NPV were determined. ROC analysis was performed to determine the diagnostic accuracy of the Hitit Index in these two patient groups. $\mathrm{p}<0.05$ was considered as statistically significant.

\section{RESULTS}

In the study, 116 COVID-19 and 110 CCHF patients were included. Median age of COVID-19 and CCHF patients was similar, being 54 and 53 years, respectively $(p=0.335) .49 .1 \%$ of COVID-19 patients and $62.7 \%$ of CCHF patients were males, and a statistically significant difference was found between the sex distribution of the patients $(p=0.040)$.

Clinical and laboratory findings (Tables 1 and 2 , respectively) frequently detected in the early stages of the disease in COVID-19 and/or CCHF were compared. Fever, malaise, headache 


\begin{tabular}{|c|c|c|c|}
\hline & CoVID-19 $(n=116), n(\%)$ & $\operatorname{CCHF}(n=110), n(\%)$ & $\mathbf{P}$ \\
\hline Fever $(+)$ & $43(37.1)$ & $74(67.3)$ & $<0.001$ \\
\hline Headache $(+)$ & $16(13.8)$ & $45(40.9)$ & $<0.001$ \\
\hline Myalgia (+) & $19(16.4)$ & $93(84.5)$ & $<0.001$ \\
\hline Malaise (+) & $47(40.5)$ & $104(94.5)$ & $<0.001$ \\
\hline Diarrhea (+) & $6(5.2)$ & $18(16.4)$ & 0.006 \\
\hline Cough (+) & $15(12.9)$ & $5(4.5)$ & 0.027 \\
\hline Nausea (+) & $0(0)$ & $42(38.2)$ & $<0.001$ \\
\hline Vomitus (+) & $0(0)$ & $18(16.4)$ & $<0.001$ \\
\hline Conjunctivitis (+) & $0(0)$ & $77(70)$ & $<0.001$ \\
\hline Facial hyperemia (+) & $0(0)$ & $54(49.1)$ & $<0.001$ \\
\hline Bleeding (+) & $0(0)$ & $18(16.4)$ & $<0.001$ \\
\hline Dizziness (+) & $0(0)$ & $9(8.2)$ & 0.001 \\
\hline Dyspnea (+) & $7(6)$ & $1(0.9)$ & 0.066 \\
\hline Chest pain (+) & $2(1.7)$ & $2(1.8)$ & 1.000 \\
\hline
\end{tabular}

p: p value; COVID-19: 2019 novel coronavirus; CCHF: Crimean-Congo hemorrhagic fever.

Table 2. Comparison of Hitit Indexes and laboratory parameters between groups

\begin{tabular}{lccc} 
& COVID-19 $(\mathrm{n}=116)$ & CCHF $(\mathrm{n}=110)$ & $\mathrm{p}$ \\
\hline Hitit Index & $-8.80(-13.1--5.50)$ & $6.30(2.05-11.4)$ & $<.001$ \\
Lymphocyte $\left(10^{3} / \mu \mathrm{l}\right)$ & $1.48(1.06-2.06)$ & $0.54(0.36-0.78)$ & $<.001$ \\
AST $(\mathrm{U} / \mathrm{L})$ & $24(18-37)$ & $119(35-240)$ & $<.001$ \\
ALT $(\mathrm{U} / \mathrm{L})$ & $20(16-31)$ & $56(23-104)$ & $<.001$ \\
Fibrinogen $(\mathrm{mg} / \mathrm{dl})$ & $374(299-488)$ & $269(210-300)$ & $<0.001$ \\
LDH $(\mathrm{U} / \mathrm{L})$ & $216(171-281)$ & $412(259-710)$ & $<0.001$ \\
CK $(\mathrm{U} / \mathrm{L})$ & $79(51-156)$ & $295(136-704)$ & $<0.001$ \\
Direct bilirubin $(\mathrm{mg} / \mathrm{dl})$ & $0.1(0.08-0.16)$ & $0.12(0.10-0.19)$ & 0.012 \\
WBC $\left(10^{3} / \mathrm{L}\right)$ & $5.96(4.30-7.49)$ & $3.00(1.98-4.61)$ & $<0.001$ \\
Neutrophil $\left(10^{3} / \mu \mathrm{l}\right)$ & $3.46(2.54-4.70)$ & $2.10(1.06-3.35)$ & $<0.001$ \\
Hematocrit $(\%)$ & $39 \pm 4.2$ & $41 \pm 4.8$ & 0.024 \\
RBC $\left(10^{6} / \mu \mathrm{l}\right)$ & $4.72 \pm 0.49$ & $4.84 \pm 0.58$ & 0.089 \\
Platelet $\left(10^{3} / \mu \mathrm{l}\right)$ & $198(162-234)$ & $88(43-137)$ & $<0.001$ \\
CKD-EPI $\left(\mathrm{ml} / \mathrm{min} / 1.73 m^{2}\right)$ & $97(77-111)$ & $93(72-106)$ & 0.222 \\
INR & $1.08(1.00-1.16)$ & $1.10(1.00-1.23)$ & 0.131 \\
\hline
\end{tabular}

p: p-value, AST: Aspartate aminotransferase, ALT: Alanine aminotransferase, LDH: Lactate dehydrogenase, CK: Creatine kinase, WBC: White blood cells, RBC: Red blood cells, CKD-EPI: Chronic Kidney Disease Epidemiology Collaboration, COVID-19: 2019 novel coronavirus, CCHF: Crimean-Congo hemorrhagic fever, INR: International normalized ratio.

*Parameters given bold are the parameters used when calculating the Hitit Index.

and myalgia, which are important symptoms for both diseases, were statistically significantly higher in patients with CCHF. Facial hyperemia, conjunctivitis and bleeding, which we consider that are specific to CCHF, were higher in patients with CCHF. Cough was statistically significantly 


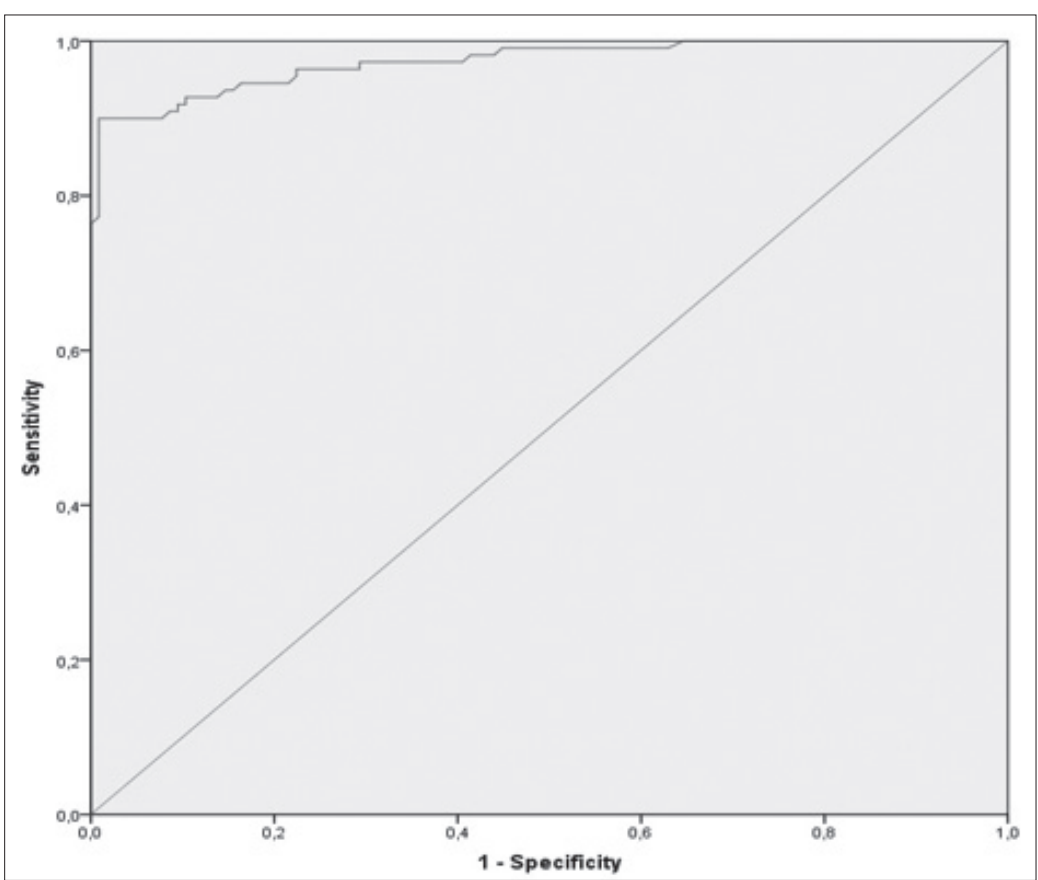

Figure 1. ROC curve analysis of Hitit Index to distinguish the patients with $\mathrm{CCHF}$ from patients with COVID-19.

higher in patients with COVID-19 ( $p=0.027)$ (Table 1).

The lymphocyte, neutrophil, leukocyte counts, and fibrinogen level used in the calculation of Hitit Index were statistically significantly lower in patients with $\mathrm{CCHF}$, as Aspartate aminotransferase (AST) and Creatine kinase (CK) activity, and Hitit Index were found to be statistically significantly higher (Table 2). The cut-off point to distinguish patients with COVID-19 from CCHF was zero. Patients with Hitit Index less and more than zero were considered as COVID-19 and CCHF, respectively. Hitit Index was negative in 115 of 116 patients with COVID-19, while it was positive in only one case. The second highest Hitit Index value in patients with COVID-19 was -0.8 , while the median value was -8.8. Hitit Index was positive in 97 of 110 patients with $\mathrm{CCHF}$, while it was negative in thirteen cases. For the Hitit Index, sensitivity and specificity were $88 \%$ and $99 \%$, while NPV and PPV were 90\% and 99\%, respectively. In Figure 1, area under ROC was 0.973 (95\% CI, 0.955-0.992; $\mathrm{p}<0.001)$.

\section{DISCUSSION}

To the best of our knowledge, this is the first study in the literature using Hitit Index to distinguish the CCHF patients from COVID-19 patients. $\mathrm{CCHFV}$ is a member of the genus Orthonairovirus in the family of Nairoviridae. CCHFV is an RNA virus with negative polarity ${ }^{[2]}$. $\mathrm{CCHF}$ which is endemic in Africa, was first seen in Turkey in 2002. CCHF cases are frequently seen between March and September every year. $\mathrm{CCHF}$ is endemic in the region of a large area including south of Black Sea coast, Middle and Eastern Anatolia. The province of Corum, where our university is located, also belongs to this region $^{[3]}$.

Coronaviruses are RNA viruses with positive polarity and SARS-CoV-2 caused a serious pandemic in the year of $2020^{[6]}$. The pandemic still continues at full speed and when it will end is unpredictable. In this period of intense pandemic, all cases admitted to the emergency services are evaluated primarily for COVID-19, and therefore other infectious diseases, especially $\mathrm{CCHF}$, which are endemic in our region, can be 
overlooked. It was determined during clinical visits in our hospital that CCHF cases were admitted to the clinics where COVID-19 cases were followed up with the pre-diagnosis of COVID-19 in the emergency service outpatient clinics. In a letter reported by Pazarli et al. indicates that to define the similarities and differences of COVID-19 and CCHF will guide physicians particularly who are not familiar with the $\mathrm{CCHF}^{[7]}$

PCR test is the definitive diagnostic method in the diagnosis of both infections, and the results of these tests can take 24 hours. The differences in transmission routes and measures to be taken for both viral infections as well as the need to start treatment quickly in both diseases reveal the need for a rapid diagnostic method until PCR tests are available. It is reported that the effectiveness of antiviral agents recommended in the treatment of both infections is higher in the early stages of the disease, which is the viremia period $^{[8,9]}$. In the early stages of $\mathrm{CCHF}$, the main protection methods are standard precautions and measures for transmission by contact, while in COVID-19, droplet tract and respiratory tract contamination measures should be applied in addition to contact precautions ${ }^{[10,11]}$.

Similar clinical and laboratory findings of both diseases, especially in initial stages, are also related to the similarity in their pathogenesis, which still has uncertain points for both infections. However, clinical findings differ in the later stages of the diseases due to the difference in target organs. While the primary targets in CCHF are hepatocyte and endothelial cells, the targets in COVID-19 are organs and tissues (nasal mucosa, bronchus, lung, heart, esophagus, kidney, stomach, bladder and ileum) where ACE-2 receptors are dense ${ }^{[12]}$.

In our study groups, symptoms such as high fever, chills, trembling, malaise, headache, myalgia, nausea, vomiting and diarrhea with conjunctivitis and facial hyperemia were significantly higher in CCHF cases. In COVID-19 cases, respiratoryrelated symptoms such as cough and dyspnea were observed more frequently than $\mathrm{CCHF}$ cases, but no significant difference was found. Although the symptoms and findings evaluated above are statistically significantly higher in patients with $\mathrm{CCHF}$, they are insufficient in distinguishing patients with COVID-19 from patients with CCHF in emergency outpatient conditions. Therefore, it was concluded that there should be other distinguishing parameters and we started investigating whether the Hitit Index which we previously created for patients with CCHF would be useful or not in distinguishing COVID-19 and CCHF patients. Parameters, which are examples of such artificial intelligence, are being used in the diagnosis of COVID-19[13]. In this article, CT imaging and clinical information have been used together for the rapid diagnosis of COVID-19 effectively.

When the parameters in the Hitit Index formula were evaluated in terms of the distinction between COVID-19 and CCHF patients, the Hitit Index was statistically significantly higher in $\mathrm{CCHF}$ patients than in COVID-19 patients. The cut-off point was taken as zero for the Hitit Index to distinguish patients with COVID-19 from patients with CCHF. Hitit Index value more or less than zero was accepted as CCHF or COVID-19, respectively.

\section{CONCLUSION}

In this study, the Hitit Index is an example of the artificial intelligence that we can use to distinguish patients with CCHF from patients with COVID-19 in the spring-summer period when the $\mathrm{CCHF}$ cases are seen, especially in regions where it is endemic. The specificity of $99 \%$ indicates that there may be just $1 \%$ of misdiagnose by use of the Hitit Index with zero cut-off point when distinguishing the patients with COVID-19 from patients with CCHF. Since the PPV was 99\%, patients with Hitit Index value more than zero should be hospitalized for the therapy of CCHF as soon as possible. One of the limitations of our study is that it was performed retrospectively from a single center and a single region. In order to further improve the Hitit Index and to increase its diagnostic power in distinguishing patients with CCHF from patients with COVID-19, we consider that more centers should work with more patients.

\section{Acknowledgments}

We thank all the study physicians and nurses from the Infectious Diseases and Clinical 
Microbiology Service in our hospital for their attentive care of patients.

\section{ETHICS COMMITTEE APPROVAL}

The ethical approval for this study was obtained from Hitit University Faculty of Medicine Clinic Research Ethics Committee (Date: 17.06.2020, Decision No: 269).

\section{CONFLICT of INTEREST}

The authors declare no conflict of interests.

\section{AUTHORSHIP CONTRIBUTIONS}

Concept and Design: DY, ÖA, AKÇ, NB

Data Collection or Processing: DY, ÖA, GK, PTÖ

Analysis/Interpretation: DY, NB, AKC , HK GK

Literature Search: DY, ÖA, NB, AKG, KH,

Writing: DY, ÖA, NB, GK, HK

Final Approval: All of authors

\section{REFERENCES}

1. Malik YA. Properties of Coronavirus and SARS-CoV-2. Malays J Pathol 2020 Apr;42(1):3-11.

2. Ergönül O. Crimean-Congo haemorrhagic fever. Lancet Infect Dis 2006 Apr;6(4):203-14.

3. Karasartova D, Gureser AS, Gokce T, Celebi B, Yapar D, et al. Bacterial and protozoal pathogens found in ticks collected from humans in Corum province of Turkey. PLoS Negl Trop Dis 2018 Apr 12;12(4):e0006395.

4. Shi Y, Wang G, Cai XP, Deng JW, Zheng L, et al. An overview of COVID-19. J Zhejiang Univ Sci B 2020 May;21(5):343360.

5. Kayadibi H, Yapar D, Akdogan O, Ulusu NN, Baykam N. Hitit Index to distinguish patients with and without Crimean-Congo hemorrhagic fever. Ticks Tick Borne Dis 2019 Aug;10(5):1035-40.
6. Guo YR, Cao QD, Hong ZS, Tan YY, Chen SD, et al. The origin, transmission and clinical therapies on coronavirus disease 2019 (COVID-19) outbreak - an update on the status. Mil Med Res 2020;7(1):11.

7. Pazarlı AC, Parlak Z, Ekiz T. COVID-19 and Crimean-Congo Hemorrhagic Fever: Similarities and Differences. Heart Lung 2020;49(6):892-3.

8. Zhang X, Zhang D, Zhang C, Yao L, Xu L, et al. COVID-19 outbreak prevention by early containment in Shantou, China. J Infect Dev Ctries 2020;14(7):742-7.

9. Yeşilbağ Z, Karadeniz A, Koçulu S, Kayhan CB. Epidemiological characteristics, clinical and laboratory findings supporting preliminary diagnosis of Crimean-Congo hemorrhagic fever in an endemic region in Turkey. Wien Klin Wochenschr 2020;132(19-20):581-8.

10. Tsergouli K, Karampatakis T, Haidich AB, Metallidis S, Papa A. Nosocomial infections caused by Crimean-Congo haemorrhagic fever virus. J Hosp Infect 2020;105(1):43-52.

11. YIImaz GR. COVID-19: hava yolu ile bulaşıyor mu? FLORA 2020;25(4):464-73.

12. Jin $Y$, Yang $H$, Ji W, Wu W, Chen S, et al. Virology, Epidemiology, Pathogenesis, and Control of COVID-19. Viruses 2020;12(4):372.

13. Mei $X$, Lee $H C$, Diao $K Y$, Huang $M$, Lin B, et al. Artificial intelligence-enabled rapid diagnosis of patients with $\mathrm{CO}$ VID-19. Nat Med 2020;26(8):1224-8.

\section{Address for Correspondence/Yazıșma Adresi}

Dr. Derya YAPAR

Hitit Üniversitesi Tıp Fakültesi,

İnfeksiyon Hastalıkları ve

Klinik Mikrobiyoloji Anabilim Dalı

Corum-Türkiye

E-posta: drderyayapar@hotmail.com 